\title{
Assessment of genetic divergence of Sesame seeds based on biochemical parameters
}

\author{
Barnali Roy ${ }^{1^{*}}$, Amit Kumar Pal ${ }^{2,}$ \& A.K. Basu ${ }^{3}$ \\ ${ }^{1}$ Department of Botany, Kanchrapara College, Kanchrapara 743 145, N 24 Pargana, West Bengal, India \\ ${ }^{2}$ Microbiology Research Laboratory, Department of Botany, University of Kalyani, Kalyani 741 235, West Bengal, India \\ ${ }^{3}$ Department of Seed Science and Technology, Faculty of Agriculture, Bidhan Chandra Krishi Viswavidyalaya, Mohanpur, West Bengal 741252, \\ India \\ *Email: barnaliroy_barnali@yahoo.com
}

\section{ARTICLE HISTORY}

Received: 13 February 2020

Accepted: 18 October 2020

Published: 01 January 2021

\section{KEYWORDS}

Sesame seeds

Oil content

lodine number

Crude and soluble protein

Genetic divergence

Heterosis

\section{ABSTRACT}

The assessment of genetic divergence plays a significant role to identify promising genotypes to initiate crossing programme for crop improvement. The sesame being a nutritious oil seed crop containing various biochemical constituents used as a good dietary choice. The biochemical analysis was done taking freshly harvested seeds of eight (8) parental genotypes and twenty one (21) advance lines. The studies revealed that all the genotypes differed significantly among themselves for all the biochemical parameters including moisture content, oil content, its iodine number and saponification value, both crude and soluble protein, some mineral matters - $\mathrm{Ca}, \mathrm{P}, \mathrm{Mn}, \mathrm{Zn}, \mathrm{Cu} \& \mathrm{Fe}$ and Carbohydrate and ascorbic acid content. Mahalanobis generalized genetic distance using $\mathrm{D}^{2}$ statistics for the assessment of genetic divergence amongst 29 genotypes based on biochemical parameters. All the genotypes were grouped into eleven distinct clusters. Maximum intra cluster divergence was noted against cluster IX with advance lines having black coloured seeds as its constituents. With regard to inter-cluster distance values the cluster $\mathrm{X}$ was mostly divergent from all other clusters and cluster II as the less divergent one from the rest. Cluster X with parental genotype B-14 was identified as superior cluster for the biochemical parameters on the basis of securing higher position for maximum number of characters. Constitution pattern clustering was independent of eco-geographical isolation. Promising segregants with higher oil yielding potentially may yield from inter se mating of advance line 14 and HT-1 with T-12, R-9 or advance lines 10,14,20.

\section{Introduction}

The increasing severe hunger throughout the world caused due to shortage of fertile cultivable land and crop production with lower nutrient contents. So, the problem of malnutrition is rising day by day especially in different developing countries. Many indigenous plants having seeds enriched with proteins, essential minerals, is of great importance to fight the developing problem. One of the potential plant is sesame, for its nutritious oil.

Sesame, belonging to the Pedaliaces (1) cultivated for its seeds which is edible and also having flavorsome value (2). The sesame seeds are small in size and the colour of seeds also varies among many varieties (3).

The sesame seed contains $50-52 \%$ oil, $17-19 \%$ protein as well as $16-18 \%$ carbohydrate (4). The sesame seed protein contains lysine, methionine and tryptophan. Moreover, the sesame seed contains vitamin $E$ and fat soluble lignans such sesamin and sesamoline (5). The sesame oil is stable and it gives long shelf life due to the presence of anti-oxidative agents like sesamin, sesamolin, sesamol, sesaminol glucosides and tocopherol $(6,7)$.

The sesame seeds have been cultivated and domesticated in the Indian sub-continent region since Harappan and Anatolian eras $(8,9)$.

The sesame is considered as a nutritious oil seed crop as various chemical constituents has been reported by several researchers. The range of moisture content was 4.9-6.2 \% (10), oil content 40.4-59.8\% (11), protein $19.4-26.3 \%$ (11), carbohydrate $14.1-18.0 \%$ (12), Different mineral contents $4.9-5.7 \%$ (13), Calcium 1.06-2.33 \% (14), Phosphorus 0.47-1.29\% (14).

(c) Roy et al (2021). This is an open-access article distributed under the terms of the Creative Commons Attribution License, which permits unrestricted use, distribution and reproduction in any medium, provided the original author and source are credited (https://creativecommons.org/licenses/by/4.0/)

To cite this article: Roy B, Pal A K, Basu A.K. Assessment of genetic divergence of sesame seeds based on biochemical parameters. Plant Science Today. 2021;8(1):1-8. https://doi.org/10.14719/pst.2021.8.1.752 
These highly important characteristics of sesame seeds have motivated the researchers to study the biochemical parameters of seeds and to study the genetic divergence of seeds based on biochemical parameters which will be used in genetic improvement in oil seed crops through hybridization programme in future The applications of sesame seeds in food products for the protection of heart and liver and to prevent tumor has been increased due to the presence of antioxidant and anti-carcinogenic components in sesame seeds. The demand of high quality oil seeds increases as the world populations increases day by day where the mal-nutrition is a major challenge in developing countries. The most important sesame producing countries are Myanmar, India and China followed by Ethiopia, Nigeria, Sudan, Uganda as well as Tanzania (15).

The productivity of sesame declines $(16,17)$ though India being self sufficient in sesame production and this may be due to lack of high yielding varieties $(18,19)$. The assessment of genetic divergence is very essential in any crop plants to get high productivity in any breeding programme. It has been reported that the sesame is believed to be originated in India where a wide diversity in genetic resources is present (20). Diversity analysis have been done based on so many desirable traits such as morphological characters like plant height, number of seeds per capsule, 1000 seed weight, seed colour etc but the analysis of genetic diversity based on morphological characteristics may be influenced by environmental bias (20, 21). Moreover, environmental influence was not recorded in the case of the biochemical studies $(21,22)$.

In this context, the aim of our study was to evaluate the genetic divergence among 29 lines of sesame based on biochemical parameters that would help in selection of superior genotypes with high nutritive value as well as high quality sesame oil also for exploitation in hybridization programme.

\section{Materials and Methods}

Eight (8) parental genotypes and 21 advanced lines of their crossing originally selected on the basis of their yield performance taken for experiment. These 21 advance lines were produced during F1 generation.

Table 1. Seed colour of different parental genotypes

\begin{tabular}{cll}
\hline Lines & Genotype & Seed colour \\
\hline 1 & Variety R-9 & Small grayish white \\
\hline 2 & Variety B-14 & Black \\
\hline 3 & Variety B-9 & Brown \\
\hline 4 & Variety B-67 & Blackish brown \\
\hline 5 & Variety T-12 & White \\
\hline 6 & Variety IDP-51 & Blackish brown \\
\hline 7 & Variety IET -2 & Light brown \\
\hline 8 & Variety HT-1 & White \\
\hline
\end{tabular}

The seeds were collected from different seed collection centre. The parental genotypes and their seed colour are as given in Table 1.
The advance lines are selected from the segregants of the following crosses:

Table 2. Advance lines showing parantage

\begin{tabular}{|c|c|c|c|}
\hline $\begin{array}{l}\text { Sl. } \\
\text { No. }\end{array}$ & $\begin{array}{l}\text { Lines (Crosses } \\
\text { between parental } \\
\text { lines) }\end{array}$ & Parentage & Seed colour \\
\hline 1. & $3 \times 5$ & B-9 9 T-12 & Brown \\
\hline 2. & $2 \times 8$ & B-14 x HT-1 & Black \\
\hline 3. & $8 \times 2$ & HT-1 x B-14 & Black \\
\hline 4. & $6 \times 5$ & IDP-51 x T-12 & Blackish Brown \\
\hline 5. & $5 \times 3$ & T-12 x B-9 & Brown \\
\hline 6. & $6 \times 2$ & IDP-51 x B-14 & Blackis Brown \\
\hline 7. & $2 \times 3$ & B-14 x B-9 & Black \\
\hline 8. & $3 \times 7$ & B-9 $\times$ IET-2 & Brown \\
\hline 9. & $3 \times 7$ & B-9 x IET-2 & Brown \\
\hline 10. & $5 \times 1$ & T-12 x R-9 & White \\
\hline 11. & $5 \times 6$ & T-12 x IDP-51 & Blackish Brown \\
\hline 12. & $2 \times 6$ & B-14 x IDP-51 & Blackish Brown \\
\hline 13. & $1 \times 7$ & R-9 x IET-2 & Grayish white \\
\hline 14. & $1 \times 8$ & R-9 x HT-1 & White \\
\hline 15. & $8 \times 2$ & HT-1 x B-14 & Black \\
\hline 16. & $7 \times 3$ & IET-2 x B-9 & Brown \\
\hline 17. & $3 \times 8$ & B-9 x HT-1 & Brown \\
\hline 18. & $7 \mathrm{x} 1$ & IET-2 x R-9 & Grayish white \\
\hline 19. & $8 \times 3$ & HT-1 x B-9 & Brown \\
\hline 20. & $1 \times 5$ & $\mathrm{R}-9 \times \mathrm{T}-12$ & White \\
\hline 21. & $7 \mathrm{x} 1$ & IET-2 x R-9 & Grayish white \\
\hline
\end{tabular}

All the genotypes were shown at District Seed Farm, D-Block, Kalyani, Nadia, West Bengal. The seeds of all the genotypes were shown in Randomized Block Design (RBD) with 3 replications in five rows plot for each genotype with row to row spacing of $25 \mathrm{~cm}$. The spacing between plant to plant was near about 12-15 $\mathrm{cm}$. All agronomic practices like soil preparation, plantation as seed showing, weed removal, frequent watering, development of soil aeration for better root growth have been done during the conduct of experiment. The maximum temperature during experiment reaches upto $39-40{ }^{\circ} \mathrm{C}$. The observation recorded on the basis of 5 randomly selected plants from each genotype per replication considering the different yield related characters. Seeds were collected from randomly selected 5 capsules from each plant of 29 genotypes were threshed and counted separately and oven dried and then weighed.

The required amount of seeds ( 1 to 5 gm for different individual tests) were taken for the analysis of various biochemical components in the Soil science laboratory, Plant physiology and Biochemistry Laboratory of BCKV, Mahanpur, Nadia. The following biochemical parameters of each genotypes including moisture content have been analyzed from the freshly harvested dry seeds.

i) Oil content

ii) Iodine member

iii) Saponification value

iv) Crude protein

v) Soluble protein

vi) Carbohydrate content

vii) Mineral matters - Ca, $\mathrm{P}, \mathrm{Mn}, \mathrm{Zn}, \mathrm{Cu}, \mathrm{Fe}$

viii) Ascorbic acid content 


\section{Determination of Moisture content}

For the determination of moisture content of the harvested seed samples of the each genotype, required amount of seeds (100 gm) were oven dried at $50-60{ }^{\circ} \mathrm{C}$ till a constant after which the seeds were weighted finally and the moisture content was determined as:

$$
\text { Moisture content }(\%)=\frac{\text { Loss in weight }}{\text { Initial weight }} \times 100
$$

The iodine number is a measure of unsaturated linkages present in the fat or oil. The methodology followed for estimation of iodine number was described (24). The estimation of saponification value was described by standard methodology (23). The crude protein of seeds was estimated based on organic nitrogen content was determined (24). The estimation of soluble protein in the sesame seed was done according to the protocol (25). The methodology of determination of carbohydrate followed by standard procedure (22).

\section{Analysis of mineral constituents}

The seeds from each of 29 genotypes were harvested and dried first in air and then in oven at $60{ }^{\circ} \mathrm{C}$ to a constant weight. Then seeds were ground in morter pastel. Representative samples (1 gm. dried powder) for each of the genotypes were digested in A. R. grade triacid mixture of $\mathrm{HNO}_{3}: \mathrm{H}_{2} \quad \mathrm{SO}_{4}$ in the ratios of 10:1:4 (26). The volume of the digested extract was made to $50 \mathrm{ml}$ with double glass distilled water and stored in plastic container after passing through WhatMan 42 filter paper. The concentrations of $\mathrm{Fe}, \mathrm{Cu}, \mathrm{Zn}$ and $\mathrm{Mn}$ in the extract were always determined by Atomic Absorption Spectrophotometer GBC double beam (AAS, Model 902) following the conditions as mentioned below:

Ca content in the extracts was determined by microprocessor controlled Flame Photometer (Chemito, Model 1020). The determination of phosphorous (P) from the same digested sample was done by using a ELICO digital spectrophotometer, Model SL 171, to Vanadomolybdophosphoric Yellow Colour Method in Nitric Acid system (24). The estimation of ascorbic acid is followed (22) and the experiment conducted in the plant physiology and Biochemistry Laboratory of BCKV. Another part of our study was genetic divergence assessment which was done by using Mahalanobis $\mathrm{D}^{2}$ statistics (27). Grouping of genotypes in to different clusters was followed by standard procedure (28).

Table 3. Wave length, Lamp current, Flame type for determination of elements

\begin{tabular}{llll}
\hline Element & Wave length & Lamp current & Flame type \\
\hline $\mathrm{Fe}$ & 248.3 & 7.0 & Air acetylene (Oxidising) \\
\hline $\mathrm{Cu}$ & 324.7 & 3.0 & - do - \\
\hline $\mathrm{Zn}$ & 213.9 & 5.0 & - do - \\
\hline $\mathrm{Mn}$ & 279.5 & 5.0 & $\begin{array}{l}\text { Air acetylene } \\
\text { (Stoichiometric) }\end{array}$ \\
\hline
\end{tabular}

\section{Analysis of variance (ANOVA)}

The differences in performance amongst the genotypes for the characters studied were tested for significance using ANOVA adopted for Randomised Block Design (RBD). The significance levels are denoted in Table 6 with asterisk.

\section{Results and Discussion}

The analysis of different biochemical parameters and oil estimation has been done from the freshly harvested seeds of 29 genotypes. The studies revealed that all the genotypes differed significantly among themselves for all the biochemical parameters. The co-efficient of variation (CV\%) was maximum (95.7851) for Mn content and it was minimum for Saponification Value (0.0745) (Table 4).

Oil content was maximum for parent 5 (T-12) and it was 10 amongst the advanced lines followed by line 20, although they were statistically indifferent from each other (Table 4). Both the advance lines 10 and 20 were the product of parent 5 (T-12) and parent 1 (R-9). The next position was occupied by line 14 selected from the segregants of Parent 1 (R-9) and Parent 8 (HT-1). All of them have the inherent potentiality of producing high oil.

As genotypes with white/light coloured seeds viz, R-9, T-12 and HT-1 were found to have high oil content, its derivative advance lines with light coloured seeds also had a tendency of having higher oil content as evidenced by line 10, 20 and 14. It is also clear from the performance of the advanced lines that the parents with high oil content were able to generate segregants with high oil content. There seems to be a strong correlation between the seed coat colour and oil content. The lighter coloured genotypes yielded more oil than the dark coloured ones (29).

Iodine number as maximum 128.76 was recorded against line 12 and as 128.71 against line 4 which were statistically indifferent from each other followed by line 17 and 14. Parent 8 (HT-1) also had the higher the iodine value as compared to other parents (Table 4). All the superior performing advanced lines exhibited heterosis over its either parents.

The higher iodine number in oil, the greater is the linkage of unsaturated fatty acids (31) which ultimately determines the oil quality and the greater the linkage of unsaturated fatty acids, it is less hazardous to human health.

The maximum saponification value of oil (190.38) was noticed in R-9 followed by line 5, 15 and 3 , all of which were derived from the segregants of crosses involving at least one inferior parent and exhibited heterosis over its superior parent (Table 4). There are reports on the basis of their observation that high saponification values of the oil indicate the higher concentration of unsaturated fatty acids (30).

Soluble protein forms an important quality component of sesame seeds. An estimate of the same was carried out in all the selected genotypes 
Table 4. Average performance of the genotypes for oil and related parameters, different protein characters, carbohydrates and Ascorbic acid content

\begin{tabular}{|c|c|c|c|c|c|c|c|}
\hline $\begin{array}{c}\text { Parents \& Adv. } \\
\text { Lines }\end{array}$ & Oil \% & Iodine No. & $\begin{array}{c}\text { Saponification } \\
\text { Value }\end{array}$ & $\begin{array}{c}\text { Soluble Protein } \\
\text { (\%) }\end{array}$ & $\begin{array}{c}\text { Crude } \\
\text { Protein (\%) }\end{array}$ & $\begin{array}{c}\text { Ascorbic Acid } \\
(\mathrm{mg} / \mathrm{gm})\end{array}$ & $\begin{array}{l}\text { Carbohydrate } \\
\text { (\%) }\end{array}$ \\
\hline $\mathrm{P}-1$ (R-9) & 46.07 & 109.98 & 190.38 & 8.33 & 20.27 & 0.0496 & 13.93 \\
\hline 2 (B-14) & 39.07 & 110.79 & 186.41 & 10.07 & 22.13 & 0.0490 & 12.13 \\
\hline 3 (B-9) & 44.23 & 110.59 & 185.37 & 6.53 & 17.53 & 0.0486 & 12.67 \\
\hline 4 (B-67) & 40.12 & 108.99 & 186.88 & 6.27 & 17.40 & 0.0496 & 13.23 \\
\hline 5 (T-12 & 46.50 & 120.46 & 185.77 & 7.77 & 19.63 & 0.0523 & 14.27 \\
\hline 6 (IDP-51) & 39.88 & 115.53 & 188.25 & 6.03 & 15.73 & 0.0486 & 13.07 \\
\hline 7 (IET-2) & 39.55 & 112.57 & 186.56 & 5.67 & 15.03 & 0.0513 & 14.23 \\
\hline 8 (HT-1) & 45.30 & 123.79 & 184.42 & 10.63 & 22.83 & 0.0496 & 14.33 \\
\hline Adv. L-1 & 43.89 & 115.47 & 185.45 & 6.83 & 17.63 & 0.0480 & 13.70 \\
\hline 2 & 42.56 & 120.18 & 187.58 & 10.07 & 22.03 & 0.0506 & 12.87 \\
\hline 3 & 40.52 & 121.49 & 188.98 & 10.63 & 22.43 & 0.0490 & 10.10 \\
\hline 4 & 42.75 & 128.71 & 186.69 & 6.13 & 15.83 & 0.0480 & 14.20 \\
\hline 5 & 43.98 & 109.44 & 190.03 & 6.57 & 17.73 & 0.0503 & 13.87 \\
\hline 6 & 39.98 & 112.49 & 185.52 & 7.00 & 18.77 & 0.0480 & 13.37 \\
\hline 7 & 41.98 & 116.30 & 186.33 & 8.17 & 21.30 & 0.0516 & 12.53 \\
\hline 8 & 40.44 & 118.58 & 185.21 & 5.23 & 16.57 & 0.0530 & 14.00 \\
\hline 9 & 41.29 & 119.19 & 187.97 & 5.07 & 16.17 & 0.0480 & 14.30 \\
\hline 10 & 45.96 & 120.17 & 186.76 & 7.47 & 19.73 & 0.0476 & 13.93 \\
\hline 11 & 40.18 & 108.99 & 185.66 & 6.13 & 19.03 & 0.0480 & 13.10 \\
\hline 12 & 41.11 & 128.76 & 186.42 & 7.40 & 21.63 & 0.0490 & 13.23 \\
\hline 13 & 40.97 & 119.99 & 184.81 & 6.70 & 19.37 & 0.0486 & 14.27 \\
\hline 14 & 44.40 & 123.98 & 186.66 & 9.27 & 20.27 & 0.0493 & 14.60 \\
\hline 15 & 41.43 & 119.97 & 189.24 & 10.67 & 22.07 & 0.0510 & 13.43 \\
\hline 16 & 42.37 & 118.15 & 187.51 & 5.43 & 16.43 & 0.0526 & 13.53 \\
\hline 17 & 42.53 & 124.24 & 186.52 & 8.37 & 19.23 & 0.0490 & 13.93 \\
\hline 18 & 43.65 & 120.28 & 187.68 & 5.60 & 16.77 & 0.0503 & 13.73 \\
\hline 19 & 42.90 & 122.23 & 186.62 & 9.17 & 20.17 & 0.0496 & 14.07 \\
\hline 20 & 45.47 & 119.13 & 185.71 & 7.77 & 19.87 & 0.0480 & 13.87 \\
\hline 21 & 42.99 & 119.04 & 185.75 & 5.57 & 15.57 & 0.0500 & 14.33 \\
\hline Mean & 42.4852 & 117.9139 & 186.7978 & 7.4667 & 18.9368 & 0.0496 & 13.6149 \\
\hline CV (\%) & 0.4978 & 0.1569 & 0.0745 & 0.8040 & 0.2920 & 1.0973 & 2.1900 \\
\hline S Em & 0.1726 & 0.1511 & 0.1135 & 0.04902 & 0.0452 & 0.00044 & 0.2435 \\
\hline $\mathrm{CD}_{0.05}$ & 0.4784 & 0.4188 & 0.3146 & 0.1358 & 0.1253 & 0.00123 & 0.6749 \\
\hline $\mathrm{CD}_{0.01}$ & 0.6287 & 0.5505 & 0.4135 & 0.1785 & 0.1646 & 0.00162 & 0.8870 \\
\hline
\end{tabular}

including their parents which revealed that line 15 occupied the highest position (10.67\%) followed by parent 8 and line $3(10.63 \%)$ and parent 2 and line 2 (10.07\%), Parent 8, lines 3 and 15 were significantly indifferent from each other (Table 4).

With regard to crude protein content also, parent 8 exhibited the highest value $(22.83 \%)$ followed by line 3, parent 2 (B-14), line 15 and line 2 . All the 3 advance lines, performing well for both the protein parameters, were selected from the segregants of the cross between B-14 and HT-1, which are also high performers. It is also to be noted that all the parents and lines exhibiting high soluble protein content also exhibited high crude protein.

It is clearly evident in Table 4 that ascorbic acid and carbohydrate content also varied significantly amongst the parents as well as amongst the advance lines. The range of ascorbic acid was recorded as $0.048-0.053 \mathrm{mg} / \mathrm{g}$ of seeds and the same in case of later, was recorded as 12.10-14.60 $\mathrm{gm} / 100 \mathrm{gm}$ material.

All the advance lines with high carbohydrate content viz. 14, 21, 9, 13, 4, 19 \& 8 were derived from the crosses involving either or both parents with high carbohydrate content viz. 14 21, 9, 13, 4, 19 \& 8 were derived from the crosses involving either or both parents with high carbohydrate content: HT-1, T-12 and IET-2. The highest ascorbic acid was estimated against line 8 followed by line 16, both of which also segregants of the crosses of parents 3 (B-9) and 7 (IET2). The seeds of later parent contained higher amount of ascorbic acid.

From Table 5, it is revealed that both macronutrients: $\mathrm{P}$ and $\mathrm{Ca}$ contents were lower in genotypes having seeds with white/light colour in comparison to genotypes with deep coloured seed. The maximum Ca percentage was recorded against parents 4 and 6 and amongst the advance lines, 7 and 9 recorded the same position. Both the advance lines were selected from the segregants of parents with deep coloured seeds. The minimum value of both $\mathrm{Ca}$ and $\mathrm{P}$ was recorded in parents 5 and 8 as well as in line 14 each of which was white seeded genotype.

On the other hand, the highest phosphorus content was recorded against parents 2 (B-14) and lines 2, 7 and 11, all these advance lines were also isolated from the segregants of the crosses where deep coloured (seed) genotypes was used as one of the parents. The mean Ca content was higher than $\mathrm{P}$ content. It was also reported higher mean P content than $\mathrm{K}$ content (31). 
A careful review of the data revealed that all the genotypes differed significantly amongst themselves for the three micronutrients Zinc (Zn), Copper (Cu) and Iron $(\mathrm{Fe})$ content ranging from 0.0256 to 0.0290 , 0.0423 to 0.0479 and 0.1349 to $0.2439 \mathrm{mg} / \mathrm{gm}$ of seeds respectively (Table 5). the seeds were Sun dried uniformly, the moisture holding capacity of the genotypes differed significantly amongst themselves. Line-21 and parent 6 recorded the highest $(13.00 \%)$ and lowest (11.33\%) amount of moisture content respectively. The significance level was denoted with asterisk in Table 6.

Table 5. Average performance of the genotypes for different minerals and moisture content

\begin{tabular}{|c|c|c|c|c|c|c|c|}
\hline $\begin{array}{c}\text { Parents \& Adv. } \\
\text { Lines }\end{array}$ & Са \% & Phosphorus \% & Mn Content & $\begin{array}{c}\text { Zn Content \& } \\
\text { Line }\end{array}$ & $\begin{array}{c}\text { Cu Contents } \\
(\mathrm{mg} / \mathrm{gm})\end{array}$ & $\begin{array}{c}\text { Fe Contents } \\
(\mathrm{mg} / \mathrm{gm})\end{array}$ & $\begin{array}{c}\text { Moisture \% } \\
(\mathrm{mg} / \mathrm{gm})\end{array}$ \\
\hline P-1 (R-9) & 1.13 & 0.49 & 0.0276 & 0.0261 & 0.0423 & 0.1391 & 12.50 \\
\hline $2(\mathrm{~B}-14)$ & 1.19 & 0.60 & 0.0366 & 0.0285 & 0.0459 & 0.2439 & 11.37 \\
\hline $3(\mathrm{~B}-9)$ & 1.19 & 0.58 & 0.0386 & 0.0290 & 0.0464 & 0.1810 & 11.43 \\
\hline 4 (B-67) & 1.20 & 0.57 & 0.0376 & 0.0288 & 0.0476 & 0.1809 & 11.37 \\
\hline $5(\mathrm{~T}-12$ & 1.07 & 0.48 & 0.0246 & 0.0256 & 0.0446 & 0.1400 & 12.93 \\
\hline 6 (IDP-51) & 1.20 & 0.57 & 0.040 & 0.0286 & 0.0466 & 0.1902 & 11.33 \\
\hline 7 (IET-2) & 1.13 & 0.55 & 0.0346 & 0.0261 & 0.0456 & 0.1690 & 12.50 \\
\hline 8 (HT-1) & 1.07 & 0.47 & 0.0240 & 0.0256 & 0.0434 & 0.1408 & 12.87 \\
\hline Adv. L - 1 & 1.14 & 0.57 & 0.0373 & 0.0263 & 0.0465 & 0.1678 & 12.33 \\
\hline 2 & 1.17 & 0.60 & 0.0350 & 0.0278 & 0.0459 & 0.218 & 12.97 \\
\hline 3 & 1.19 & 0.59 & 0.0376 & 0.0274 & 0.0458 & 0.2107 & 12.47 \\
\hline 4 & 1.14 & 0.54 & 0.0323 & 0.0265 & 0.0449 & 0.180 & 11.83 \\
\hline 5 & 1.18 & 0.58 & 0.0383 & 0.0283 & 0.0479 & 0.1820 & 12.53 \\
\hline 6 & 1.17 & 0.57 & 0.0376 & 0.0285 & 0.0477 & 0.1933 & 12.87 \\
\hline 7 & 1.20 & 0.60 & 0.0383 & 0.0287 & 0.0467 & 0.2095 & 12.67 \\
\hline 8 & 1.18 & 0.56 & 0.0363 & 0.0272 & 0.0479 & 0.2108 & 12.93 \\
\hline 9 & 1.20 & 0.56 & 0.0366 & 0.0273 & 0.0459 & 0.212 & 12.67 \\
\hline 10 & 1.18 & 0.55 & 0.0283 & 0.0258 & 0.0436 & 0.1451 & 11.70 \\
\hline 11 & 1.18 & 0.60 & 0.0366 & 0.0275 & 0.0459 & 0.1741 & 12.60 \\
\hline 12 & 1.16 & 0.57 & 0.0386 & 0.0285 & 0.0461 & 0.221 & 11.53 \\
\hline 13 & 1.17 & 0.54 & 0.0343 & 0.0262 & 0.0458 & 0.1738 & 12.97 \\
\hline 14 & 1.09 & 0.48 & 0.0256 & 0.0257 & 0.044 & 0.1389 & 12.63 \\
\hline 15 & 1.18 & 0.59 & 0.0336 & 0.0278 & 0.0456 & 0.2343 & 11.53 \\
\hline 16 & 1.19 & 0.57 & 0.0363 & 0.0275 & 0.0463 & 0.1790 & 12.97 \\
\hline 17 & 1.19 & 0.56 & 0.0386 & 0.0277 & 0.0463 & 0.1759 & 12.77 \\
\hline 18 & 1.17 & 0.55 & 0.0340 & 0.0262 & 0.0450 & 0.1650 & 12.63 \\
\hline 19 & 1.18 & 0.57 & 0.0356 & 0.0278 & 0.0461 & 0.173 & 12.80 \\
\hline 20 & 1.19 & 0.54 & 0.0286 & 0.0258 & 0.0436 & 0.1349 & 11.73 \\
\hline 21 & 1.16 & 0.53 & 0.0336 & 0.0263 & 0.0446 & 0.1428 & 13.00 \\
\hline Mean & 1.1657 & 0.5551 & 0.0383 & 0.0273 & 0.0457 & 0.1803 & 12.3598 \\
\hline CV (\%) & 0.7511 & 1.2547 & 95.7851 & 0.3186 & 1.0540 & 0.1182 & 0.6205 \\
\hline S Em & 0.0071 & 0.0056 & 0.0299 & 0.00007 & 0.0004 & 0.0002 & 0.0626 \\
\hline $\mathrm{CD}_{0.05}$ & 0.0196 & 0.0155 & NS & 0.00019 & 0.0011 & 0.0005 & 0.1735 \\
\hline $\mathrm{CD}_{0.01}$ & 0.0258 & 0.0204 & NS & 0.00025 & 0.0014 & 0.0007 & 0.2280 \\
\hline
\end{tabular}

The $\mathrm{Zn}$ content was as high as $0.0290 \mathrm{mg} / \mathrm{g}$ seeds of B-9 followed by B-67 and advance line 7. The lines 5, 6, 7 and 12 with higher $\mathrm{Zn}$ content were isolated from the segregants of the crosses involving at least one parent with high $\mathrm{Zn}$ content. The highest $\mathrm{Cu}$ content was estimated against advance lines 5 and 8 followed by line 6 and B-67. All these higher performing lines were also derived from the cross involving at least one parent with high $\mathrm{Cu}$-content. The maximum Fe content of $0.2439 \mathrm{mg} / \mathrm{g}$ of seeds was estimated against parent 2 (B-14) followed by lines 15 , 12 and 2, all being derived from the crosses between B-14 with either HT-1 or IDP-51. All the parents and advance lines with white/light coloured seeds contained less amounts of all the micronutrients including Mn content in comparison to the genotypes with deep coloured seeds.

In spite of significant variation, highest Mn content was estimated against IDP-51 followed by B-9 and advance lines 12 and 17, both the advance lines were initially isolated as recombinants of IDP-51 and B-9 respectively, the higher Mn containing parents. Though
Assessment of genetic divergence revealed significant difference among the 29 genotypes based on 14 biochemical parameters. Genetic divergence was estimated using Mahalanobis $\mathrm{D}^{2}$ statistics (27). 21 advance lines along with their 8 parents were grouped into 11 clusters based on 14 biochemical parameters including moisture content and the clustering was followed by Torcher's method (28). The composition of different clusters has been shown in Table 7. In this Table it is noted that cluster IV was constituted with maximum number of genotypes of which 3 were parental genotypes and cluster VII, VIII, X and $\mathrm{XI}$ having single genotypes each as its constituent unit. Cluster VII and X were constituted with parental genotypes 8 (HT-1) and 2 (B-14) respectively. While, cluster VIII and XI were constituted with advance lines 4 and 21 respectively. Cluster I and IX were constituted with 2 genotypes each. 3 genotypes for each of cluster II, $\mathrm{V}$ and VI were included as their constituents. But cluster III was constituted with 5 genotypes of 
which two were parental genotypes with light coloured seeds namely R-9 and T12 along with three advance lines also having light coloured seeds (Table 7).

The clustering pattern and distribution of genotypes within various clusters indicates the absence of association between eco-geographical distribution of genotypes and genetic divergence. This observation was supported by the findings in
The average performance of all the clusters for all the fourteen biochemical characters is shown in Table 9. Cluster X occupied either highest or next highest position for seven characters of which Fe, Zn, P and $\mathrm{Ca}$ were remarkable indicating higher contribution of those parameters in clustering of the genotypes.

Cluster III showing highest average value for oil content recorded higher values for saponification, carbohydrate and ascorbic acid only. Whereas

Table 6. ANOVA table for biochemical characters

\begin{tabular}{|c|c|c|c|c|c|c|c|c|c|c|c|c|c|c|}
\hline Source & $\begin{array}{l}\text { D. } \\
\text { F }\end{array}$ & Oil \% & $\begin{array}{c}\text { Iodine } \\
\text { no. }\end{array}$ & $\begin{array}{l}\text { Saponifi- } \\
\text { cation } \\
\text { Value }\end{array}$ & $\begin{array}{c}\text { Soluble } \\
\text { Protein \% }\end{array}$ & $\begin{array}{c}\text { Crude } \\
\text { Protein } \\
\%\end{array}$ & $\begin{array}{c}\text { Calciu } \\
\text { m \% }\end{array}$ & $\begin{array}{l}\text { Phospho- } \\
\text { rous \% }\end{array}$ & $\begin{array}{l}\text { Carboh- } \\
\text { ydrate \% }\end{array}$ & $\underset{(\mathrm{mg} / \mathrm{gm})}{\mathrm{Mn}}$ & $\underset{(\mathrm{mg} / \mathrm{gm})}{\mathrm{Zn}}$ & $\underset{(\mathrm{mg} / \mathrm{gm})}{\mathrm{Cu}}$ & $\begin{array}{c}\text { Fe } \\
(\mathbf{m g} / \mathrm{gm})\end{array}$ & $\begin{array}{c}\text { Moisture } \\
\text { content } \\
(\mathrm{mg} / \mathrm{gm})\end{array}$ \\
\hline $\begin{array}{l}\text { Replicatio } \\
\mathrm{n}\end{array}$ & 2 & 0.1094 & 0.1250 & 0.1250 & 0.0227 & 0.0049 & 0.001 & 0.0007 & 0.0444 & 0.0013 & $-0.3725 \times 10^{-5}$ & $0.4172 \times 10^{-6}$ & $0.1192 \times 10^{-6}$ & 0.0098 \\
\hline Treatment & 28 & $\begin{array}{r}13.9234 * \\
*\end{array}$ & $94.6547^{* *}$ & $6.6667^{* *}$ & $9.3574^{* *}$ & $16.6551^{* *}$ & $0.0040^{* *}$ & $0.0037^{* *}$ & $1.3851^{* *}$ & $0.0015^{\mathrm{NS}}$ & $0.3862 \times 10^{-}$ & $0.5741 \times 10^{-5 * *}$ & $0.0028^{* *}$ & $1.0584^{* *}$ \\
\hline Error & 56 & 0.447 & 0.0342 & 0.0193 & 0.0036 & 0.0030 & 0.00008 & 0.00005 & 0.0889 & 0.0013 & $0.7539 \times 10^{-8}$ & $0.2321 \times 10^{-6}$ & $0.4537 \times 10^{-7}$ & 0.0059 \\
\hline
\end{tabular}

rice (32). Genetic divergence can play important role because hybrid between parental lines of diverse origin usually show a better heterosis than those between closely related strains.

The values of inter and intra clusters distances are shown in Table 8. It was revealed that cluster IX was found to have maximum intra-cluster distance which may be due to the inclusion of advance lines 12 and 15 as its constituents which were derived from the segregant of the crosses of B- 14 (Black seed) with IDP-51 (Blackish brown seed) and HT-1 (White seed). The intra-cluster distances were recorded to be zero against cluster VII, VIII, $\mathrm{X}$ and XI due to the inclusion of single genotype each as their constituent. The inter-cluster distance was as high as 568.827 between cluster III and $\mathrm{X}$ followed by the same between VII \& X and X \& XI.

Table 7. Clustering pattern, size and constituents involving 29 genotypes for biochemical parameters

\begin{tabular}{|c|c|c|}
\hline Cluster No. & $\begin{array}{l}\text { No. of } \\
\text { constituent } \\
\text { Genotype (s) }\end{array}$ & Genotypes \\
\hline $\mathrm{I}$ & 2 & Advance line 8 and 9 \\
\hline II & 3 & Advance line 17,19 and 13 \\
\hline III & 5 & T 12, Advance line 20,10,14 and R 9 \\
\hline IV & 7 & $\begin{array}{l}\text { B 67, B 9, Advance line 5, Advance line- } \\
\text { 11, IDP - 51, Advance line } 16 \text { and } \\
\text { Advance line } 6\end{array}$ \\
\hline V & 3 & $\begin{array}{l}\text { Advance line } 1 \text {, Advance line } 18 \text { and } \\
\text { IET }-2\end{array}$ \\
\hline VI & 3 & $\begin{array}{l}\text { Advance line } 1 \text {, Advance line } 3 \text { and } \\
\text { Advance line }-7 \text {. }\end{array}$ \\
\hline VII & 1 & $\mathrm{HT}-1$ \\
\hline VIII & 1 & Advance line 4 \\
\hline IX & 2 & Advance line 12 and Advance line 15 \\
\hline $\mathrm{X}$ & 1 & B -14 \\
\hline $\mathrm{XI}$ & 1 & Advance line -21 \\
\hline
\end{tabular}

For all the three higher inter-cluster distances, cluster $\mathrm{X}$ being constituted with single parental genotype B-14, contributed significantly for the said information. The higher inter-cluster distance values indicated that cluster $\mathrm{X}$ was most diversely related with cluster III, VII, XI respectively, though they were less divergent amongst themselves. On an average, cluster $\mathrm{X}$ was also identified as mostly divergent from all other clusters and cluster II as the less divergent one from the rest. cluster VII showed higher average value for oil content produced maximum value for protein content, both soluble and crude, as well as carbohydrate content. The contribution of Fe content towards clustering of the genotypes was as high as $77.83 \%$ followed by crude protein and iodine number, the contribution of oil content for the same was minimum. Therefore, it can be stated that inter se mating of B-14 with members of III, VII and XI may produce recombinants with higher values for almost all chemical parameters, especially for iron, crude protein and iodine number. Inter se mating between constituent of cluster III and HT-1, constituent of cluster VII may also lead to the production of desirable segregants where oil content is be given prime importance for selection (Table 9).

\section{Conclusion}

Present study was carried out on genetic diversity of 29 genotypes based on different biochemical parameters. The studies revealed that all the genotypes differed significantly among themselves for all the biochemical parameters. It is clear from the performance of the advance lines that the parents with high oil content were able to generate segregants with high oil content. All the superior performing advance lines exhibited heterosis over its either parent. It is also noted that all the parents and lines exhibiting high soluble protein content also exhibited high crude protein. In our work it was noted that all the parents and advance lines with white/light coloured seeds contained less amount of all the micronutrients including $\mathrm{Mn}$ content in comparison with the genotypes with deep coloured seeds. So the characterization of various components of sesame seeds and the assessment of genetic divergence of genotypes is very important in plant breeding which determine the selection of parents to sustain high level of productivity of edible oil. The success of hybridization programme in crop plants is primarily dependent upon the genetic diversity of parents involved in crossing programme. The higher intercluster distance values indicated that cluster $\mathrm{X}$ was most diversely related with cluster III, VII, XI respectively, though they were less divergent amongst 
Table 8. Average intra cluster (diagonal) and inter cluster distance (D values) on the basis of 14 chemical parameters

\begin{tabular}{|c|c|c|c|c|c|c|c|c|c|c|c|}
\hline & I & II & III & IV & V & VI & VII & VIII & IX & $\mathbf{x}$ & XI \\
\hline I & 23.489 & & & & & & & & & & \\
\hline II & 227.168 & 56.235 & & & & & & & & & \\
\hline III & 403.692 & 196.798 & 71.227 & & & & & & & & \\
\hline IV & 169.795 & 128.30 & 264.286 & 73.447 & & & & & & & \\
\hline $\mathrm{V}$ & 246.742 & 114.280 & 182.480 & 119794 & 67.805 & & & & & & \\
\hline VI & 153.319 & 214.724 & 395.521 & 208.959 & 283.548 & 64.932 & & & & & \\
\hline VII & 424.617 & 204.046 & 101.821 & 299.173 & 230.179 & 388.769 & 0.000 & & & & \\
\hline VIII & 190.013 & 98.939 & 240.095 & 129.936 & 111.904 & 230.261 & 262.598 & 0.000 & & & \\
\hline IX & 175.216 & 297.012 & 480.925 & 282.008 & 360.999 & 110.107 & 473.346 & 295.585 & 94.602 & & \\
\hline $\mathrm{X}$ & 227.747 & 387.723 & 568.827 & 345.295 & 437.549 & 190.404 & 568.167 & 387.584 & 133.398 & 0.000 & \\
\hline $\mathrm{XI}$ & 371.389 & 198.301 & 112.291 & 235.291 & 137.214 & 400.778 & 184.189 & 205.467 & 481.326 & 564.810 & 0.000 \\
\hline
\end{tabular}

Table 9. Cluster means for 14 chemical characters and contribution of each cluster towards diversity

\begin{tabular}{lrrrrrrrrrrrr}
\hline \multicolumn{1}{c}{ Characters } & $\begin{array}{c}\text { Contribu } \\
\text { tion }\end{array}$ & \multicolumn{1}{c}{ I } & \multicolumn{1}{c}{ II } & III & IV & V & VI & VII & VIII & IX & X & XI \\
\hline 1. Oil & 0.25 & 40.86 & 42.133 & 45.68 & 41.53 & 42.36 & 41.68 & 45.30 & 42.75 & 41.27 & 39.07 & 42.99 \\
\hline 2. Iodine No. & 8.13 & 118.885 & 122.15 & 118.744 & 112.025 & 116.106 & 119.32 & 123.79 & 128.71 & 124.36 & 110.79 \\
\hline 3.Saponification Value & 0.50 & 186.59 & 185.98 & 187.056 & 187.03 & 186.56 & 187.63 & 184.42 & 188.69 & 187.83 & 186.41 & 119.04 \\
\hline 4. Soluble protein & 1.724 & 5.15 & 8.08 & 8.122 & 6.28 & 6.033 & 9.623 & 10.63 & 6.13 & 9.035 & 10.07 & 5.57 \\
\hline 5.Crude protein & 8.62 & 16.37 & 19.63 & 19.95 & 17.517 & 16.476 & 21.92 & 22.83 & 15.83 & 21.85 & 22.13 & 15.57 \\
\hline 6. Ca & 0.25 & 1.19 & 1.18 & 1.13 & 1.187 & 1.146 & 1.186 & 1.07 & 1.14 & 1.17 & 1.19 & 1.16 \\
\hline 7. Phosphorus & 0.25 & 0.56 & 0.55 & 0.508 & 0.577 & 0.556 & 0.596 & 0.47 & 0.54 & 0.58 & 0.60 & 0.53 \\
\hline 8. Carbohydrate & 0.25 & 14.15 & 14.09 & 14.12 & 13.262 & 13.886 & 12.50 & 14.33 & 14.20 & 13.33 & 12.13 & 14.33 \\
\hline 9. Mn & 0.25 & 0.03645 & 0.03616 & 0.0269 & 0.0366 & 0.0353 & 0.0369 & 0.0240 & 0.0323 & 0.0361 & 0.0366 & 0.0336 \\
\hline 10. Zn & 0.25 & 0.02725 & 0.0272 & 0.0258 & 0.0283 & 0.0262 & 0.0279 & 0.0256 & 0.0265 & 0.02815 & 0.0285 & 0.0263 \\
\hline 11. Cu & 0.25 & 0.0469 & 0.0460 & 0.0436 & 0.0469 & 0.0457 & 0.04613 & 0.0434 & 0.0449 & 0.0458 & 0.0459 & 0.0446 \\
\hline 12. Fe & 77.83 & 0.2114 & 0.1742 & 0.1396 & 0.18292 & 0.1672 & 0.2127 & 0.1408 & 0.180 & 0.2276 & 0.2439 & 0.1428 \\
\hline 13. Ascorbic acid & 0.25 & 0.0505 & 0.049 & 0.0494 & 0.0493 & 0.0498 & 0.0477 & 0.0496 & 0.048 & 0.05 & 0.049 & 0.05 \\
\hline 14. Moisture & 1.23 & 12.8 & 12.8 & 12.298 & 12.157 & 12.486 & 12.703 & 12.87 & 11.83 & 11.53 & 11.37 & 13.00 \\
\hline
\end{tabular}

themselves. On an average, cluster $\mathrm{X}$ was also identified as mostly divergent from all other clusters and cluster II as the less divergent one from the rest. Therefore, the greater the genetic distance between two clusters, the wider the genetic diversity among the parents to be included in hybridization programme. Parents combining higher oil yield potential with wide genetic diversity are likely to produce superior segregants within a reasonable period.

\section{Acknowledgements}

The authors would like to acknowledge the financial help from DST-PURSE programme of Department of Science and Technology, GoI, India.

\section{Authors' contributions}

BR conducted the experiments and collected the data. AKP supported in the experimental works, writing the manuscript and performed statistical analysis. AKB hypothesized the paper concept and designed the experiment.

\section{Conflict of interests}

The authors have no conflict of interest.

\section{References}

1. Bedigian D. Characterization of sesame (Sesamum indicum L.) germplasm: a critique. Genet. Resour. Crop Evol. 2010;57(5):641-47. https://doi.org/10.1007/s10722-010-9552-x
2. Devorajan S, Chatterjee B, Urata H, Zhang B, Ali A, Singh R et al. Enteral sesame oil therapeutically relieves disease severity in rat experimental osteoarthritis. Am J Med. 2016.

3. Alpaslan M, Boydak E, Hayta M, Gerçek S, Simsek M. Effect of row space and irrigation on seed composition of Turkish sesame (Sesamum indicum L.). Journal of the American Oil Chemists' Society. $2001 \quad$ Sep;78(9):933-35. https://doi.org/10.1007/s11746-001-0366-0

4. Martinchik AN. Nutritional value of sesame seeds. VoprPitan. 2011;80(3):41-46. 1668.2011.01066.x

https://doi.org/10.1111/j.1939

5. Pathak N, Rai AK, Kumari R, Bhat KV. Value addition in sesame: A perspective on bioactive components for enhancing utility and profitability. Pharmacognosy reviews. 2014 Jul;8(16):147. $\quad$ https://doi.org/10.4103/0973-7847.134249 PMid:25125886 PMCid:PMC4127822

6. Suja KP, Jayalekshmy A, Arumughan C. Free radical scavenging behavior of antioxidant compounds of sesame (Sesamum indicum L.) in DPPH• system. Journal of Agricultural and Food Chemistry. 2004 Feb 25;52(4):912-15. https://doi.org/10.1021/jf0303621

7. Bedigian D, Seigler DS, Harlan JR. Sesamin, sesamolin and the origin of sesame. Biochemical Systematics and Ecology. 1985 May 23;13(2):133-39. https://doi.org/10.1016/03051978(85)90071-7

8. Bedigian D. Evolution of sesame revisited: domestication, diversity and prospects. Genetic Resources and Crop Evolution 2003 Nov 1;50(7):779-87. https://doi.org/10.1023/A:1025085012808

9. Cheng FC, Jinn TR, Hou RC, Tzen JT. Neuroprotective effects of sesamin and sesamolin on gerbil brain in cerebral ischemia. International Journal of Biomedical Science: IJBS. 2006 Sep;2(3):284

10. Menezes FG, Budowski P, Dollear FG. Sesame oil. II. Some chemical and physical properties of the oils from different varieties of sesame seed. Journal of the American Oil Chemists Society. https://doi.org/10.1007/BF02634414
May;27(5):184-86. 
11. Yermanos DM, Hemstreet S, Saleeb W, Huszar CK. Oil content and composition of the seed in the world collection of sesame introductions. Journal of the American Oil Chemists' Society. 1972 Jan;49(1):20-23. https://doi.org/10.1007/BF02545131

12. Krishnamurthy $\mathrm{K}$, Ramakrishnan $\mathrm{TN}$, Rajagopalan $\mathrm{R}$, Swaminathan M, Subrahmanyan V. The effect of heat processing on the trypsin inhibitor and nutritive value of protein of soybean. Ann. Biochem. Exp. Med. 1958;18:153-6.

13. Krishnamurthy K, Tasker PK, Ramakrishnan TN, Rajagopalan $\mathrm{R}$, Swaminathan M. Studies on the nutritive value of sesame seeds. 1. The amino-acid composition of the proteins and the chemical composition of white and black varieties of sesame seed and meal. Annals of Biochemistry and Experimental Medicine. 1960;20:73-6.

14. Carter FL, Cirino VO, Allen LE. Effect of processing on the composition of sesame seed and meal. Journal of the American Oil Chemists Society. 1961 Mar 1;38(3):148-50. https://doi.org/10.1007/BF02641238

15. Tubiello FN, Salvatore M, Rossi S, Ferrara A, Fitton N, Smith P. The FAOSTAT database of greenhouse gas emissions from agriculture. Environmental Research Letters. 2013 Feb 12;8(1):015009.

16. Oyeogbe A, Ogunshakin R, Vaghela S, Patel B. Towards sustainable intensification of sesame-based cropping systems diversification in northwestern India. Food Secur. 2015;3(1):1-5.

17. FAOSTAT F. Agriculture Organization of the United Nations FAO statistical database Available from: http://faostat. fao. org. Accessed June. 2015;30.

18. Duhoon, S.S. Exploitation of heterasis for raising productivity in sesame in new directions for a diverse planet: Proceedings of the $4^{\text {th }}$ International Crop Science Congress, Brisbane, Australia 2004; Vol. 26.

19. Ram SG, Sundaravelpandian K, Kumar M, Vinod KK, Bapu JK, Raveendran TS. Pollen-pistil interaction in the inter-specific crosses of Sesamum sp. Euphytica. 2006 Dec 1;152(3):379-85. https://doi.org/10.1007/s10681-006-9225-1

20. Banerjee PP, Kole PC. Analysis of genetic architecture for some physiological characters in sesame (Sesamum indicum L.) $\begin{array}{lc}\text { Euphytica. } & \text { 2009 }\end{array}$

$1 ; 168(1): 11-22$.

1. Tabatabaei I, Pazouki L, Bihamta MR, Mansoori S, Javaran MJ, Niinemets U. Genetic variation among Iranian sesame (Sesamum indicum L.) Accessions vis-a-vis exotic genotypes on the basis of morpho-physiological traits and rapd markers. Australian Journal of Crop Science. 2011;5(11):1396.

22. Sadasivam S, Manikam A. Biochemical Methods for Agricultural Sciences. Wiley Eastern Limited and Tamil Nadu Agricultural University Publication. 1992.

23. Sankaram A. Laboratory Manual for Agriculture: Chemistry. Asia Publishing House; 1966.

24. Jackson ML. Nitrogen determinations for soil and plant tissue. Soil Chemical Analysis. 1958:183-204.

25. Lowry OH, Rosebrough NJ, Farr AL, Randall RJ. Protein measurement with the Folin phenol reagent. Journal of Biological Chemistry. 1951;193:265-75.

26. Jackson ML. Phosphorus determination for soils. In: Soil Chemical Analysis, Prentice-hall of India Pvt. Ltd., New Delhi. 1967; pp:134-82.

27. Mahalanobis PC. On the generalized distance in statistics. National Institute of Science of India 1936.

28. Rao CR. Advanced Statistical Method in Biometrics Research John Wiley and Sons Ind. New York, 1952; pp 390.

29. The Wealth of India Raw Materials, Vol. IX-Rh-So, Publications and Information Directorate, New Delhi. 1988;pp. 278-92.

30. Dashak DA, Fali CN. Chemical composition of four varieties of Nigerian benniseed (Sesamum indicum). Food Chemistry. 1993 Jan 1;47(3):253-55. https://doi.org/10.1016/0308-8146(93)90157-B

31. Murthy IYL., Singh M, Sastry JA. Some macro and micro nutrients in sesame seeds. J. Oilseeds Research. 1997;14(1):12425.

32. Bansal UK, Saini RG, Rani NS, Kaur A. Genetic divergence in quality rice. Oryza. 1999;36(1):20-23. 